\title{
The Dilemma and Marketing Strategies of Paper Media under the Background of "Internet +"
}

\author{
Yang Heng ${ }^{1}$ \\ ${ }^{1}$ Business College, Guangzhou Vocational College of Technology \&Business, Guangzhou, \\ Guangdong, China, 514442 \\ ${ }^{a}$ email
}

Keywords: Internet Plus, Internet +, Paper Media, New Media

\begin{abstract}
With the rapid development of internet and mobile internet, the survival and development of media have been hammered. The paper media needs to seek a way out. This paper analyzes the current situation and dilemma of the paper media, compares the paper media and the new media, expounds the reading habits and psychological of readers in the mobile internet era and explores the marketing strategies of paper media development.
\end{abstract}

\section{Current Situation and Dilemma of Paper Media}

The paper media refers to the traditional sense of the newspapers, magazines and other media with the paper as the carrier. From the birth date, paper media has a long history. In history, it has a glorious achievement, plays an important role in people's life, work and study. China's newspaper media includes party newspaper, city newspaper, professional newspaper and regional newspapers etc. The magazine can be divided into two categories: comprehensive periodical and professional periodical. New media is using digital technology, network technology, through the Internet, broadband local area network, wireless communication network, satellite channels, and computers, mobile phones, digital TV terminal to provide users with information and entertainment services communication form.

In recent years, with the rapid development of internet and mobile internet, the survival and development of media have been hammered. People's reading habits have changed.A part of the group losesinterest in the paper media, leading to a sharp drop in the number of paper readers. Today's paper media is faced with the cost of printing and issuing way is single; the propagation speed is slow, high labor costs, advertising revenue decline and other issues. In the past few years, some newspapers have failed to survive the cold winter of 2015.Zawenbao under the Hebei Daily newspaper industry shut down in January 2015. The Xinbao in Hong Kong which has nearly 60 years of history went bankrupt in July2015. Shanghai quantity issued biggest business daily "Shanghai Business" in October 2015 officially closed. Throughout the north and south, a lot of media have made changes and adjustments. In October 2015, the Southern Metropolis Daily started the new century twelfth revision. In the same month, the Chongqing Morning Post published revised declaration, announced on November, embrace change. Shenyang Evening News launched to raise the public. Under the background of "Internet plus", paper media is in face of big development challenges, needing to seek a phoenix road. 


\section{Comparison between Paper Media and New Media}

The development of new media doesnot mean that the traditional paper mediadoesn't have any advantages. In fact, paper media and new media have their own strengths and weaknesses and theyhave their own advantages and shortcomings. The table shows the paper media and new media in the professional degree, collection degree, reading content degree, aging degree, profit degree, interest degree and the original degree and reliability of comparative analysis.

\begin{tabular}{|c|c|c|}
\hline & Paper Media & New Media \\
\hline $\begin{array}{l}\text { Professional } \\
\text { Degree }\end{array}$ & $\begin{array}{l}\text { The news editorial staff have } \\
\text { corresponding qualification }\end{array}$ & $\begin{array}{l}\text { low professional degree due to } \\
\text { unstandardized qualification }\end{array}$ \\
\hline $\begin{array}{l}\text { Collection } \\
\text { Degree }\end{array}$ & can be collected and read repeatedly & too much information to collect \\
\hline Content & profound content & $\begin{array}{l}\text { information is rich and highly } \\
\text { fragmented }\end{array}$ \\
\hline Timeliness & $\begin{array}{l}\text { bad timelessness and long } \\
\text { manufacturing process }\end{array}$ & $\begin{array}{l}\text { good timelessness and can report news } \\
\text { simultaneously }\end{array}$ \\
\hline Profit & $\begin{array}{l}\text { single profit model, the main income } \\
\text { source is advertisement }\end{array}$ & aims at maximizing pro \\
\hline Interest & little interest and interactivity & $\begin{array}{l}\text { master the users' interest, have high } \\
\text { interactivity with users }\end{array}$ \\
\hline Origin & good origin degree of news & be lack of origin \\
\hline Credibility & $\begin{array}{l}\text { high credibility due to rigorous } \\
\text { review }\end{array}$ & $\begin{array}{l}\text { be difficult to distinguish true and } \\
\text { false }\end{array}$ \\
\hline
\end{tabular}

\section{Reading Habits and Psychology of Readers in the Mobile Internet Era}

Reading Habits and Psychology of Readers of the Children. Nowadays, the children are growing up in the internet era. Part of the children's childhoodis exposure to the internet media, like reading in mobile phones, tablet PCs and mobile internet media.The visual, auditory, tactile reading let them fresh feelings. But children's reading habits are affected by their family, especially their parents. A large part of the parents prefer to give children to read paper media, such as the children's story books and illustrated books.

Reading Habits and Psychological of Readers of the Youth. According to the Twelfth National Reading survey by China News Publishing Institute in 2015, the adultsof our country read information from the Wechat for more than 40 minutes every day. The digital reading rate is more than the traditional reading ratefor the first time, andthe higher the education background, the longer the reading time. In the digital reading group, the higher the education level, the higher the degree of cognition and acceptance of the network reading. The youth is the main group who read through mobile Internet media.They prefer to accept new things, and they are keen on mobile phones, tablet PCs, mobile media reading.They also like interactive reading, quick and convenient way of reading.Because of their busy pace of life and work, they tend to fragmentation of reading. For 
example, they tend to read duringeating in the subway, bus, elevators, and other leisure timeto get the information. But it cannot be ignored that there are still some young readers who like holding a piece of newspaper or a magazine to feel the quiet fun of reading.

Reading Habits and Psychological of Readers of the Middle-aged. Middle aged group gradually began to contact with the internet media.A small number of them who have advanced thinking try to catch up with the trend of new media and read on the new media. However, a large number of middle-aged people are still accustomed to obtain information from paper media but they find that the information given by the paper media is less than before.So they began to catch up with the new media reading and the pace of the times.

Reading Habits and Psychological of Readers of the Old. The old reader group seldom uses the mobile Internet devices. They prefer to get information throughthe paper media. They like deep reading and enjoythe texture of thepaper. With the development of the Internet, a very small number of the old begins to use the mobile internet media, like the micro-blog and Wechat. They try their best to readin themobile phones, tablet PCs and other digital devices.

\section{Marketing Strategies of Paper Media}

Improve Operation System. The traditional media operation mechanism is too old. The managersare often the news persons, who are good at the practical news operation.In addition, the media reporter are only responsible for the general interview, writing, and do not assume marketing tasks. Now the media needs to improve the operation of the system, and be close to the marketing. Paper media can set up the project platform, such as real estate platform, food platform, the car platform, the platform by the reporter and the management team together. Each team should responsible for its own profits and losses, and promote the traditional media to the market. What's more, we can also promote the internal business and incubatemarket projects which have great power and good potential, then the newspaper and the founder of the project can share the profits.

Innovate Marketing Channels. Paper media should innovative marketing channels. The paper mediawill not disappear. However, it is not a feasible way to spread information only by paper. The website, mobile terminal and mobile phone APP are the future media channels. The news reading experienced a process from paper to PC and mobile phoneAPP. Paper can strengthen the cooperation of the mobile phone operators to develop their own mobile app and implant its brand to the mobile phone app. A lot of brand mobile phones will come with some software when they are produced. Thus thepaper media can get closer to its readers through the cooperation with the mobile phone brand. The paper media can develop its own implanted APP in the phones to cultivate the readers from the mobile phone users.

Optimize Layout Content. True and reliable original materials, excellent professional editorial team, full of creative visual angle of news are the paper media advantages. It has the ability to construct the core content of the paper, which is the most authoritative and important form of media. The development of Internet and digital technology has brought the massive information resources and channels, but valuable content is scarcer. The Internet media also continues to expand the professional team, recruiting, enough to see the professional media. In the era of digital media, the real value, the depth of the media will be retained, as people like holding a connotation magazine to enjoy again and again, a unique insight into the newspaper repeatedly reading. On the contrary, people tend to readthe tabloid news faster on the Internet. Since the paper media is difficult to catch up with the internet media in speed, but it can play its own strengths, like the news deep tracking, interpretationand interviews. 
Emphasize Production Technology. In the new media era, people's lifestyle, ways of communication, way of thinking and mode of action have changed. The public enjoysthe instant informationbrought bynew media. The advanced media technology is the representative of all social media. The micro-blog, Wechat and forums can create blasting explosive news,whichcauses the discussion upsurge of National. Paper media should establish a technology driven product development thinking and technology media application in the transition. Some transformation of the paper media has two-dimensional code technology into paper layout, only need to scan a newspaper or a magazine on the two-dimensional code, tracking subsequent news reports, and then we can know the story which is behind the news. In addition, the magazines will be the two-dimensional micro channel stacking at the end of the paper.Readers can scan on the micro channel to communicate with the author. We set the scan two-dimensional code towatch video and other functions. It can help the readers to read statically and have the dynamics of perception.

Construct Integrated Marketing Platform. The paper media should consider the integration of resources and the construction of integrated marketing platform. The paper has accumulated a lot of resources in the long process of development.If we can integrate these resources, we will create more wealth. Real estate paper can be combined with real estate intermediary and real estate companies to build real estate circles, with the information of real estate services.Fashion paper can be combined with various brands, pop stars and celebrities to create the fashion circle, and provide the service of fashion information.The finance and economics newspapers can hold sometheme activities andbuildsome investment and financing platform. Tourism paper can hold some travel tourism exhibition to build tourism circle.

Innovative Marketing Thinking. The traditional media people should change the traditional means of communication andbreak the traditional media architecture, making paper media as the news release center. Then, the online news and the offline news are combined. Paper media people can spread the key content in Wechat Subscription, official micro-blog, official news websites, mobile app, and the platform. Itcan expand the depth of the content in the new media and attract people to read the contents offline.At the same time, readers can publish their own views and comments on the online platform. Some of the comments can become the information itself. Online is the way for people to get information and we can get the specific contentoffline. The combination of online and offline can enhance the interaction and presentation of news.

\section{References}

[1] Wan Xueqi, Combination of Paper Media and New Media—a Case Research of “Dahe Daily”, D., Zhengzhou University, 2014.

[2] Wang Yanqing, On Development Strategies of Traditional Paper Media in iPad Times, J., Journal of Hunan University of Science \&Technology (Social Science Edition), 2013, 16(1): 164-167.

[3] Fu Ping, Zhang Xiaodong, The Paper Media Transformation in the Internet Age-Taking the Times as an example, Journalism \& Communication Review, 2015(4): 253-259.

[4] PiZehong, Thinking about the Strategic Transformation of the Traditional Paper Media, J., New Economy, 2014(13): 27-32. 